\title{
ANALISIS BEBAN KERJA SUMBER DAYA MANUSIA (SDM) KESEHATAN DI PUSKESMAS CIWIDEY KABUPATEN BANDUNG MENGGUNAKAN METODE WORKLOAD INDICATORS OF STAFFING NEED (WISN)
}

\author{
Gugum Pamungkas ${ }^{1)}$, Eem Kusmiati ${ }^{2)}$ \\ ${ }^{1,2)}$ Sekolah Tinggi Ilmu Kesehatan Dharma Husada Bandung \\ 'gugumpamungkas@gmail.com \\ eemkusmiati71@gmail.com
}

\begin{abstract}
ABTRAK
Kunjungan pasien yang datang periksa ke Puskesmas Ciwidey yaitu dengan rata- rata kunjungan pasien per hari 120 -170 orang dan per bulan rata-rata kunjungan 2000-2500 orang. Tujuan penelitian ini adalah untuk menganalisis beban kerja Sumber Daya Manusia (SDM) Kesehatan di Puskesmas Ciwidey Kabupaten Bandung menggunakan metode Workload Indicators of Staffing Need (WISN). Jenis penelitian ini menggunakan deskriptif analitik. Populasi dalam penelitian ini adalah 21 responden. Teknik sampling dalam penelitian ini diambil dengan menggunakan sampling jenuh berjumlah 21 responden. Hasil penelitian diperoleh waktu kerja tersedia tahun 2018 berdasarkan jumlah kerja efektif di Puskesmas Ciwidey adalah 2,017 Jam / Tahun atau 121,050 Menit. Beban kerja petugas kesehatan di Puskesmas Ciwidey yang memiliki beban kerja tinggi adalah dokter umum, dokter gigi, perawat gigi, perawat, bidan, apoteker, rekam medis, promkes dan yang memiliki beban kerja rendah adalah tenaga gizi, sanitarian sedangkan analis memilki beban kerja sedang. Standar kelonggaran waktu di Puskesmas Ciwidey adalah 1,063, Jumlah SDM tenaga kesehatan dengan menggunakan metode WISN di Puskesmas Ciwidey dibutuhkan sebanyak 31 orang petugas kesehatan. Penelitian ini maka disarankan Kepada Puskesmas Ciwidey Penambahan jumlah SDM perlu segera diusulkan untuk mengurangi beban kerja dengan menggunakan anggaran yang ada baik dari dana Biaya Oprasional Kesehatan (BOK) ataupun dari dana Badan Layanan Umum Daerah (BLUD) atau kapitasi sehingga bisa mengatasi pengurangan beban kerja dari masing masing tenaga kesehatan yang ada.
\end{abstract}

Kata Kunci : Beban kerja, SDM Kesehatan

\section{PENDAHULUAN}

Untuk mencapai Universal Health

Coverage (UHC) Sumber Daya Manusia

(SDM) Kesehatan mutlak diperlukan.

Menurut WHO, Indonesia termasuk dalam 57

negara yang menghadapi krisis tenaga

kesehatan. Padahal $80 \%$ keberhasilan

pembangunan kesehatan ditentukan Sumber

Daya Manusia (SDM) Kesehatan. ${ }^{1}$

Menurut PPSDMK Kemenkes RI tahun

2013 jumlah Sumber Daya Manusia (SDM)
Kesehatan yang tercatat sebanyak 877.088 orang. Terdiri dari 681.634 tenaga kesehatan dan 195.454 tenaga non kesehatan. Tenaga kesehatan terdiri dari 90.444 Tenaga Medis, 288.405 Perawat, 137.110 Bidan, 40.181 Tenaga Farmasi, dan 125.494 tenaga kesehatan lainnya.

Kurangnya SDM Kesehatan di Indonesia bisa dimaknai sebagai kurangnya jumlah SDM Kesehatan atau distribusi yang tidak merata. ${ }^{2}$ Dalam rangka pemenuhan SDM Kesehatan 
diperlukan perencanaan kebutuhan tenaga kesehatan yang dapat mengantisipasi kebutuhan lokal, nasional dan global.

Undang-Undang No.36 Tahun 2014 tentang Tenaga Kesehatan, pasal 14 ayat 2 menyatakan perencanaan tenaga kesehatan disusun secara berjenjang (dimulai dari fasilitas pelayanan kesehatan, Pemerintah Daerah Kabupaten/Kota, Pemerintah Daerah Provinsi, sampai dengan Pemerintah secara nasional) berdasarkan ketersediaan tenaga kesehatan dan kebutuhan penyelenggaraan pembangunan dan upaya kesehatan. ${ }^{3}$

Sesuai dengan Permenkes No. 33 Tahun 2015, bahwa Perhitungan kebutuhan SDM Kesehatan wajib dilaksanakan salah satunya oleh fasilitas kesehatan dibawah koordinasi Dinas Kesehatan Kabupaten/Kota untuk fasilitas kesehatan di tingkat Kabupaten/Kota. Penyusunan perencanaan kebutuhan Sumber Daya Manusia (SDM) Kesehatan sesuai dengan tanggung jawab dan kewenangannya, maka dimulai dari bawah yakni ditingkat institusi dimulai dari puskesmas. ${ }^{4}$ Terkait hal itu di dalam Kemenkes RI No. 81 Tahun 2004 tentang Pedoman Penyusunan Perencanaan SDM Kesehatan di tingkat Provinsi, Kabupaten/Kota serta rumah sakit disebutkan bahwa salah satu cara dalam perencanaan kebutuhan tenaga kesehatan di Institusi Kesehatan adalah berdasarkan beban kerja dengan menggunakan metode Workload Indicators of Staffing Need (WISN).

Metode WISN merupakan penghitungan kebutuhan tenaga kesehatan berdasarkan beban kerja nyata yang dilaksanakan oleh setiap Jurnal Penelitian Kesehatan STIKes Dharma Husada Bandung kategori tenaga kesehatan pada tiap unit kerja di fasilitas pelayanan kesehatan. ${ }^{5}$ Berdasarkan Peraturan Menteri Kesehatan Republik Indonesia Nomor 75 Tahun 2014 tentang Pusat Pelayanan Kesehatan Masyarakat (Puskesmas) sumber daya manusia terdiri dari Tenaga Kesehatan dan Tenaga Non Kesehatan. Jenis dan jumlah Tenaga Kesehatan dan Tenaga Non Kesehatan dihitung berdasarkan analisis beban kerja, dengan mempertimbangkan jumlah pelayanan yang diselenggarakan, jumlah penduduk dan persebarannya, karakteristik wilayah kerja, luas wilayah kerja, ketersediaan fasilitas pelayanan kesehatan tingkat pertama lainnya di wilayah kerja, dan pembagian waktu kerja. Tenaga Kesehatan minimal yang harus tersedia di puskesmas terdiri dari Dokter atau Dokter Layanan Primer, Dokter Gigi, Perawat, Bidan, Tenaga Kesehatan Masyarakat, Tenaga Kesehatan Lingkungan, Ahli Teknologi Laboratorium, Tenaga Gizi dan Tenaga Kefarmasian. $^{6}$

Puskesmas merupakan fasilitas kesehatan tingkat pertama yang sangat penting keberadaannya di tingkat wilayah Kecamatan., yang memiliki tugas istimewa dari puskesmas adalah menyelenggarakan unit kesehatan masyarakat (UKM) dan unit kesehatan perorangan (UKP). Salah satu tugas dan fungsi sebagai penyelenggara UKM dan UKP ini puskesmas wajib melaksanakan peningkatan kompetensi sumber daya manusia puskesmas termasuk memenuhi kebutuhan tenaga kesehatan yang bertugas di puskesmas tersebut. Untuk memenuhi kebutuhan sumber daya manusia di puskesmas, maka bisa diukur 
JURNAL SEHAT MASADA VOLUME XV

dengan beban kerja setiap SDM yang sesuai dengan perundang-undangan sehingga bisa mengetahui seberapa banyak SDM yang diperlukan untuk memenuhi tugas di

Semua Kabupaten/Kota di Jawa Barat pemenuhan kebutuhan SDM Kesehatan di puskesmas masih belum terpenuhi target sampai tahun 2019 jenis tenaga kesehatan Dokter Umum, Dokter Gigi, dan Bidan, sementara tenaga kesehatan lainnya ada beberapa Kabupaten/Kota yang memenuhi target ketersediaan tenaga berdasarkan rasio 100.000 penduduk walaupun komposisinya masih minim, diharapkan paling tidak semua ketersediaan tenaga kesehatan berdasarkan tempat kerja/fasilitas pelayanan kesehatan sesuai klasifikasinya dapat dipenuhi. ${ }^{7}$

Berdasarkan Profil Sumber Daya Manusia (SDM) Kesehatan Dinas Kesehatan Kabupaten Bandung tahun 2018 jika melihat dari Permenkes Nomor 75 Tahun 2014 SDM Kesehatan yang bertugas di setiap puskesmas pada umumnya sudah terpenuhi tetapi distribusi tenaga medis ataupun tenaga kesehatan lainnya secara umum masih dirasakan kurang apabila dilihat dengan rasio jumlah kunjungan pasien ke puskesmas dengan populasi penduduk Kabupaten Bandung cukup besar yaitu 4.069.872 jiwa. $^{8}$

Berdasarkan survei pendahuluan pada Puskesmas Ciwidey Kabupaten Bandung diketahui bahwa jumlah Sumber Daya Manusia Kesehatan atau tenaga kesehatan berjumlah 21 orang yang terdiri dari Dokter Umum 2 orang, Dokter Gigi 1 orang, Perawat puskesmas. ${ }^{6}$

4 orang, Perawat Gigi 1 orang, Bidan Puskesmas 4 orang, Bidan Desa 2 orang, Apoteker 1 orang, Asisten Apoteker 1 orang, Analis 1 orang, Petugas Gizi 1 orang, Petugas Kesling 1 orang, Petugas Rekam Medis 2 orang di pendaftaran. Jika melihat dari jumlah SDM Kesehatan di Puskesmas Ciwidey berdasarkan Permenkes Nomor 75 Tahun 2014 sudah terpenuhi karena berdasarkan penghitungan memakai rasio jumlah penduduk per 100.000 jumlah penduduk ${ }^{9}$ Tetapi apabila dilihat dari rasio kunjungan pasien yang datang periksa ke Puskesmas Ciwidey yaitu dengan rata- rata kunjungan pasien per hari $120-170$ orang dan per bulan rata-rata kunjungan 20002500 orang.

Berdasarkan data yang didapat 1 orang Dokter Umum memeriksa pasien sebanyak 50 - 70 orang per hari standarnya 20 orang. Dokter gigi memberikan pelayanan kesehatan gigi dan mulut per hari 20-30 orang. Perawat 1: 30 orang standar beban kerja 15 orang. Perawat Gigi memeriksa dan merawat 1: 20 orang standar 1: 8 orang, Bidan 1; 8 orang standarnya 1:5 orang, Analis 1;20 orang standar 1:10, Apoteker 1: 150 standarnya 1;50 orang.

Hal ini menyebabkan SDM Kesehatan bekerja tidak sesuai standar pelayanan dan beban kerja SDM kesehatan meningkat dengan beban kerja tinggi banyak mengeluh kelelahan dan bisa menyebabkan kesalahan diagnosis dan tindakan medis, disamping itu mutu pelayanan kesehatan tidak optimal sesuai Standar Oprasional Prosedur (SOP) dengan benar, seperti administrasi atau rekam medis 
tidak ditulis lengkap dan capaian kinerja program upaya kesehatan. Dampak lain secara tekhnis bagi SDM kesehatan lainnya bisa menyebabkan kesalahan dalam melaksanakan SOP (Standar Operasional Prosedur) sehingga akan berpengaruh kepada kualitas palayanan kesehatan dan capaian kinerja. Selain itu akan terjadi ketidakadilan beban kerja setiap SDM Kesehatan yang bekerja di puskesmas. ${ }^{9} \quad 6$ Menurut penelitian Ni wayan Sri wangi dkk tentang Analisis Perencanaan Sumber Daya Manusia (SDM) Kesehatan puskesmas dengan Metode Workload Indicators of Staffing Need di Kabupaten Lombok Barat Tahun 2017 mengatakan bahwa "Metode rasio belum dapat mencerminkan kebutuhan riil tenaga kesehatan berdasarkan beban kerja". Perencanaan kebutuhan tenaga kesehatan dengan melakukan analisis beban kerja menurut Peraturan Menteri Kesehatan (Permenkes) Nomor 75 Tahun 2014 tentang Pusat Kesehatan Masyarakat (Puskesmas) dirasa lebih tepat.

Salah satu metode yang dapat dipakai untuk menghitung beban kerja dan mengestimasi jumlah kebutuhan SDMK adalah dengan metode Workload Indicators of Staffing Need (WISN). Metode ini akurat dipakai untuk menghitung kebutuhan SDM Kesehatan berdasarkan pada beban pekerjaan nyata yang dilaksanakan oleh setiap kategori SDM Kesehatan pada tiap unit kerja di fasilitas pelayanan kesehatan. Hasil WISN menggambarkan permasalahan perencanaan SDM dari segi beban kerja, jumlah kebutuhan tenaga dan distribusinya. ${ }^{6,10}$ Jurnal Penelitian Kesehatan STIKes Dharma Husada Bandung
Berdasarkan latar belakang di atas penulis tertarik melakukan penelitian analisis beban kerja Sumber Daya Manusia (SDM) Kesehatan di Puskesmas Ciwidey Kabupaten Bandung menggunakan metode Workload Indicators of Staffing Need (WISN) dikarenakan kelebihan metode ini mudah dioperasikan, mudah digunakan, secara teknis mudah diterapkan, komprehensif dan realistis. ${ }^{10,11}$

\section{METODE PENELITIAN}

Penelitian ini menggunakan metode penelitian deskriptif kuantitatif dengan pendekatan observasi dan studi dokumentasi. Metode deskriptif adalah suatu metode penelitian yang dilakukan dengan tujuan utama untuk membuat gambaran atau deskriptif tentang suatu keadaan objek yang dirancang secara objektif dan data yang diperoleh secara langsung dari responden.

Metode pengumpulan data dalam Penelitian ini menggunakan teknik pendekatan waktu secara cross sectional. Dalam cross sectional, variabel yang ada pada objek penelitian diukur atau dikumpulkan secara simultan/dalam waktu yang bersamaan. ${ }^{22}$ Pengumpulan data yaitu dengan mengkaji dokomentasi beban kerja Sumber Daya Manusia (SDM) Kesehatan di Puskesmas Ciwidey dan melakukan observasi pada setiap SDM Kesehatan apabila sedang melaksanakan pekerjaan berpedoman pada SOP yang berlaku memakai stopwatch.

Populasi adalah wilayah generalisasi yang terdiri dari objek/subjek yang mempunyai kuantitas dan karakteristik tertentu yang 
ditetapkan oleh peneliti untuk dipelajari dan kemudian ditarik kesimpulannya. ${ }^{17}$ Populasi dalam penelitian ini adalah seluruh Sumber Daya Manusia (SDM) Kesehatan berdasarkan pendidikan Kesehatan di Puskesmas Ciwidey Kabupaten Bandung sebanyak 21 orang. Penelitian ini menggunakan metode sampling jenuh yakni teknik penentuan sampel bila semua anggota populasi digunakan sebagai sampel. Hal ini sering dilakukan bila jumlah populasi relatif kecil, kurang dari 30 orang atau penelitian yang ingin membuat generalisasi dengan kesalahan yang sangat kecil. Istilah lain sampel jenuh adalah sensus, dimana semua anggota populasi dijadikan sampel. ${ }^{23}$ Sampel dalam penelitian ini adalah seluruh populasi yaitu seluruh Sumber Daya Manusia (SDM) Kesehatan yang ada di Puskesmas Ciwidey dengan latar belakang pendidikan kesehatan yang berjumlah 21 orang.

\section{HASIL DAN PEMBAHASAN}

Menurut Permenkes No. 33 Tahun 2015 tentang penyusunan perencanaan kebutuhan Sumber Daya Manusia salah satu metode yang digunakan untuk menghitung kebutuhan kebutuhan SDM yaitu dengan analisis Beban Kerja. Analisis beban kerja bertujuan untuk merencanakan kebutuhan Sumber Daya Manusia di tingkat pelayanan sesuai dengan beban kerja sehingga diperlukan kebutuhan Sumber Daya Manusia.Analisis beban kerja digunakan untuk perencanaan kebutuhan Sumber Daya Manusia di fasilitas Kesehatan.
Salah satu metode yang digunakan untuk menghitung kebutuhan Sumber Daya Manusia yaitu WISN (Workload Indicators of Staffing Need), WISN adalah metode perhitungan kebutuhan Sumber Daya Manusia sesuai dengan beban kerja di tiap unit, dalam penelitian ini menghitung kebutuhan Sumber Daya Manusia di Puskesmas Ciwidey.

Data hasil penelitian :

\section{(a). Unit kerja dan kategori SDM Kesehatan di Puskesmas Ciwidey.}

Menurut Permenkes No. 55 tahun 2013 kegiatan pelayanan pasien dilakukan oleh ahli SDM Kesehatan. Berdasarkan hasil observasi dan wawancara kategori petugas kesehatan. Pada saat penelitian terdapat petugas dengan kategori pendidikan petugas di Puskesmas bagian pendaftaran sudah diploma dan sarjana, sudah pernah mengikuti diklat atau mengikuti pelatihan.

Petugas kesehatan diharapkan terus meningkatkan standar kualitas sebagai petugas kesehatan yang mampu menguasai seluruh tugas dan fungsi pokok. Unit kerja Sumber Daya Manusia Kesehatan atau tenaga kesehatan di Puskesmas Ciwidey berjumlah 21 Unit dan 21 SDM kesehatan yang terdiri dari Dokter Umum 2 orang yang saat ini 1 orang sedang cuti hamil selama 3 bulan, Dokter Gigi 1 orang, Perawat 3 orang, Perawat Gigi 1 orang, Bidan Puskesmas 4 orang, Bidan Desa 2 orang, Apoteker 1 orang, Asisten Apoteker 1 orang, Analis 1 orang, Petugas Gizi 1 orang, Promkes 1 orang, Petugas Kesling 1 orang, Petugas Rekam Medis 2 orang di pendaftaran. 
(b). Waktu Kerja yang Tersedia/Available Working Time (AWT) pada setiap SDM Kesehatan di Puskemas Ciwidey.

Menurut Keputusan Menteri Kesehatan No.81/MENKES/ SK///2004 waktu kerja tersedia tujuannya adalah diperoleh waktu kerja efektif dalam setahun masing-masing kategori Sumber Daya Manusia yang bekerja di suatu unit atau institusi Puskesmas. Dari Hasil perhitungan didapatkan waktu kerja tersedia sebesar 2,017 Jam / Tahun atau 121,050 Menit. Puskesmas Ciwidey sudah memperhitungkan hari kerja setiap 1 bulan petugas mendapat 10 hari libur nasional, cuti tahunan sebanyak 12 hari/tahun, waktu kerja tersedia tebagi menjadi beberapa shift rata-rata perhitungannya setiap shift selama 7,5 jam.

\section{(c). Komponen beban kerja SDM Kesehatan di Puskesmas Ciwidey.}

Berdasarkan teori bahwa komponen beban kerja merupakan aktivitas terpenting yang dilakukan tenaga kesehatan dalam jadwal harian bekerja. Komponen beban kerja terdiri dari aktivitas utama pelayanan kesehatan yang dilakukan oleh seluruh staf dalam suatu kategori staf dan pada aktivitas ini terdapat pencatatan yang rutin, aktivitas penunjang yang dilakukan oleh seluruh staf dalam suatu kategori staf namun tidak dilakukan, aktivitas tambahan yang tidak dilakukan oleh seluruh staf dan pada aktivitas ini tidak diperlukan suatu pencatatan yang rutin. Mengidentifikasikan/standar aktifitas yaitu terdiri dari kegiatan.
Berdasarkan komponen beban kerja didapatkan bahwa dokter umum memiliki beban kerja yang tinggi dengan hasil penghitungan waktu pertahun 711.792 menit, Dokter Gigi memilki beban kerja yang tinggi dengan hasil penghitungan waktu pertahun 122.920 menit, Perawat Gigi memiliki beban kerja yang tinggi dengan hasil penghitungan waktu pertahun 172.320 menit, Perawat memiliki beban kerja yang tinggi dengan hasil penghitungan waktu pertahun 495.160 menit,

Tenaga Gizi memiliki beban kerja yang rendah dengan hasil penghitungan waktu pertahun 57.484 menit, Bidan memiliki beban kerja yang tinggi dengan hasil penghitungan waktu pertahun 171.540 menit, Apoteker memiliki beban kerja yang tinggi dengan hasil penghitungan waktu pertahun 171.540 menit,

Sanitarian memillki beban kerja yang rendah dengan hasil penghitungan waktu pertahun 8.520 menit, Rekam Medis memiliki beban kerja yang tinggi dengan hasil penghitungan waktu pertahun 302.400 menit. Tenaga Promkes memiliki beban kerja yang tinggi dengan hasil penghitungan waktu pertahun 170.800 menit, Analis memiliki beban kerja yang sedang dengan hasil penghitungan waktu pertahun 117.000 menit.

\section{(d). Standar aktifitas SDM Kesehatan di Puskesmas Ciwidey}

Standar aktivitas adalah waktu yang diperlukan oleh seorang pekerja terlatih, terampil dan mempunyai motivasi untuk melakukan aktivitas sesuai dengan standar profesional pada lingkungan kerja setempat. 
Standar aktivitas terdiri dari standar pelayanan dan standar kelonggaran. Standar pelayanan adalah standar aktivitas utama pelayanan kesehatan yang dapat dinyatakan dalam dua indikator yaitu sebagai unit time atau rata-rata waktu yang diperlukan seorang tenaga kesehatan untuk memberikan pelayanan kesehatan kepada pasien yang yang dan rate of working atau rata-rata jumlah aktivitas yang diselesaikan dalam kurun waktu tertentu. Sedangkan standar kelonggaran adalah standar aktivitas pada aktivitas penunjang dan tambahan yang terdiri dari dua jenis yaitu Category Allowance Standard (CAS) dan Individual Allowance Standard (IAS). CAS digunakan untuk menghitung waktu dari aktivitas yang dilakukan oleh seluruh staf dalam suatu kategori yang dinyatakan dalam persentase waktu kerja sedangkan IAS digunakan untuk menghitung waktu dari aktivitas yang tidak dilakukan oleh seluruh staf dalm suatu kategori dan dinyatakan dalam waktu kerja aktual.

Standar aktifitas SDM Kesehatan di Puskesmas Ciwidey rata-rata membutuhkan waktu 26,23 menit.

\section{(e) Beban kerja standar / Standar Workload SDM Kesehatan di Puskesmas Ciwidey}

Menurut Keputusan Menteri Kesehatan No.81/MENKES/ SK/I/2004 beban kerja adalah banyaknya jenis pekerjaan yang harus diselesaikan oleh tenaga kesehatan profesional dalam satu tahun di sarana pelayanan kesehatam.
Berdasarkan standar beban kerja didapatkan bahwa Dokter Umum memiliki beban kerja yang tinggi, Dokter Gigi memiliki beban kerja yang tinggi, Perawat Gigi memiliki beban kerja yang tinggi, Perawat memiliki beban kerja yang tinggi, Gizi memiliki beban kerja yang rendah, Bidan memiliki beban kerja yang tinggi, Apoteker memiliki beban kerja yang tinggi, Sanitarian memiliki beban kerja yang rendah, Rekam Medis memiliki beban kerja yang tinggi, Promkes memiliki beban kerja yang tinggi dan Analis memiliki beban kerja yang sedang.

Standar beban kerja dipengaruhi oleh lamanya per kegiatan yang dilakukan oleh petugas kesehatan yaitu menanyakan jenis pasien baru/lama, menanyakan data sosial, menulis data pasien pada form, menulis buku register, anamnesa, hasil pemeriksaan dan sebagainya.

\section{(f). Faktor kelonggaran/ Allowance Factor SDM Kesehatan di Puskesmas Ciwidey}

Menurut Keputusan Menteri Kesehatan No.81/MENKES/ SK/I/2004 standar kelonggaran bertujuan untuk diperolehnya faktor-faktor kelonggaran setiap kategori SDM jenis kegiatan yang tidak berkaitan langsung atau dipengaruhi tinggi rendahnya kualitas atau jumlah kegiatan pokok atau pelayanan. Jumlah faktor kelonggaran kategorial di Puskesmas Ciwidey adalah 0,059 dengan Standar Kelonggaran Kategori $($ SKLG) $=1,063$ Waktu kelonggaran yang diberikan oleh petugas sudah sesuai dengan deskripsi waktu kelonggaran menurut metode WISN dimana 
waktu kelonggaran diberikan untuk keperluan rapat dan istirahat.

\section{(g) Jumlah Tenaga Kerja atau SDM Kesehatan yang dibutuhkan berdasarkan analisis metode Workload Indicators of Staffing Need (WISN)}

Menurut Keputusan Menteri Kesehatan

No.81/MENKES/ SK/I/2004 kebutuhan SDM tujuannya adalah diperolehnya jumlah dan jenis/kategori SDM per unit kerja sesuai beban kerja sesuai beban kerja selama 1 tahun. Dari hasil perhitungan yang dilakukan peneliti kebutuhan jumlah SDM tenaga kesehatan dengan menggunakan metode WISN di Puskesmas Ciwidey kondisi riil saat ini adalah 21 petugas kesehatan dengan jumlah kebutuhan sebanyak 31 orang petugas kesehatan, bisa disimpulkan bahwa kekuarangan petugas kesehatan di Puskesmas Ciwidey sebanyak 10 petugas kesehatan.

\section{KESIMPULAN}

Setelah dilakukan penelitian analisis beban kerja sumber daya manusia (SDM) kesehatan di Puskesmas Ciwidey Kabupaten Bandung menggunakan metode Workload Indicators of Staffing Need (WISN), maka diambil kesimpulan sebagai berikut :

a. Waktu kerja tersedia tahun 2018 berdasarkan jumlah kerja efektif di Puskesmas Ciwidey adalah 2017 jam / tahun atau 121.050 Menit.

b. Standar beban kerja petugas kesehatan di Puskesmas Ciwidey adalah dokter umum memiliki beban kerja yang tinggi, Dokter Gigi memiliki beban kerja yang tinggi, Jurnal Penelitian Kesehatan STIKes Dharma Husada Bandung
Perawat Gigi memiliki beban kerja yang tinggi, Perawat memiliki beban kerja yang tinggi, Gizi memiliki beban kerja yang rendah, Bidan memiliki beban kerja yang tinggi, Apoteker memiliki beban kerja yang tinggi, Sanitarian memiliki beban kerja yang rendah, Rekam Medis memiliki beban kerja yang tinggi, Promkes memiliki beban kerja yang tinggi dan Analis memiliki beban kerja yang sedang.

c. Standar kelonggaran waktu di Puskesmas Ciwidey adalah 1,063.

d. Jumlah SDM tenaga kesehatan dengan menggunakan metode WISN di Puskesmas Ciwidey kondisi riil saat ini adalah 21 petugas kesehatn dengan jumlah kebutuhan sebanyak 31 orang petugas kesehatan, terdapat kekurangan petugas kesehatan di Puskesmas Ciwidey sebanyak 10 petugas kesehatan.

\section{DAFTAR PUSTAKA}

1. Nurhotimah.2015."Analisis Beban Kerja Untuk SDM Kesehatan" http://mediakom.sehatnegeriku.com/analisis -beban-kerja-untuk-sdm-kesehatan/ diakses 23 Maret 2019. Jam 01.30.

2. Mudayana, AA. 2010" Pengaruh Motivasi dan Beban Kerja Terhadap Kinerja Karyawan di rumah Sakit Nurhidayah Bantul" Jurnal, Kes mas. 2010; 4(2):84-92

3. Undang- undang No.36 Tahun 2014 tentang tenaga kesehatan.

4. Permenkes No.33 Tahun 2015 tentang Pedoman Penyusunnan Perencanaan Kebutuhan SDM Kesehatan.Kemenkes RI Tahun 2015.

5. Kepmenkes RI No.81 Tahun 2004 Tenatng Pedoman Penyusunan Perencanaan SDM Kesehatan tingkat Propinsi. Depkes RI 2004. 
6. Permenkes RI No.75 Tahun 2014 Tentang Pusat Kesehatan Masyarakat, Kemenkes RI Tahun 2014.

7. Profil SDM Kesehatan Propinsi Jawa Barat Tahun 2016. http://www.depkes.go.id/resources/downloa d/profil/PROFIL_KES_PROVINSI_2016/1 2_Jabar. Diakses tgl 18 Maret 2019 Jam 02.25 WIB. Propil Dinas Kesehatan Kabupaten Bandung tahun 2017.

8. Profil Dinas Kesehatan Kabupaten Bandung Tahun 2017.

9. Profil Puskesmas Ciwidey Tahun 2018. WHO.

10.Niwayan Sri Wangi,Agustin., Siti Nurmayatin. 2017." Analisis Perencanaan Sumber Daya Manusia (SDM) Kesehatan Puskesmas dengan metode Workload Indicators Staffing of Need (WISN) di Kabupaten Lombok Barat" JMM Thesis. https://jmm.unram.ac.id/index.php/jurnal/ar ticle/download/108/1, diakses tanggal 01 April 2019 Jam 02.30 WIB

11.Workload Indicators Staffing of Need. Geneva: WHO Press; 2010

12.Desy Setiani, Arifudin,Sakka, Saptaputra. 2016. "Analisis Kebutuhan Dokter Umum Menggunakan Metode Workload Indicator Staffing of Need (WISN) di Rumah Sakit Umum Daerah Kabupaten Muna Tahun 2016" Jurnal..JIMKESMAS VOL .1/no.4/ Oktober 2016; ISSN 250-73IX.

13.Dharmayuda, Wulandari,Wirawan. 2015. "Analisis Beban Kerja Dokter Umum di Puskesmas Kota Denpasar dengan Menggunakan Metode Workload Indicatrors Staffing of Need (WISN)". Jurnal Public Health and Preventive medicine Archive.

14. Ni Luh Ade Kusuma Ernawati, Nursalam, Lilik Djuari. 2011 "Kebutuhan Rill Tenaga Perawat Dengan Metode Workload Indikator Staffing of Need (WISN) (The
Real Need of Nurses Based on Workload Indicator Staff Need (WISN))". Jurnal Ners Vol. 6 No. 1 April 2011: 85-92.

15. Zakky. 03 Juni 2018 "Pengertian Analisis Menurut Para Ahli, KBBI dan Secara Umum"https://www.zonarefrensi.com, diakses tanggal 23 Maret 2019 jam 02.00 WIB.

16.https://rhyerhiaty.wordpress.com./2012/12/ 25/inputprosesoutputmenurudonabedi,diaks es tanggal 23 Maret 2019 jam.02.30 WIB.

17. Rachmawati.2008.Manajemen Sumber Daya Manusia .CV Andi Offset.Jogyakarta:2008.

18. Undang-Undang No.36 tahun 2009 tentang Kesehatan. Depkes RI 2009.

19. Muchlisin Riadi. Rabu 10 Januari 2018. "Pengertian, Dimensi dan Pengukuran Beban Kerja"

https://www.kajianpustaka.com/2018/01/p engertian-dimensi-dan-pengukur. Diakses tanggal 18 Maret 2019 Jam 22.30 WIB.

20. Dinas Kesehatan Kabupaten Lebak Provinsi Banten. 18 Juli 2017 "Sumber Daya manusia Kesehatan". http://dinkes.lebakkab.go.id/sumber-dayamanusia-kesehatan/diakses tanggal 8 April 2019, Jam 18.38 WIB.

21. Kementrian Kesehatan Republik Indonesia. 2017. "Pelatihan Manajemen Puskesmas". Jakarta: Pusat Pelatihan SDMK Badan PPSDM Kemenkes RI. 2017.

22. Budiman. 2011. Penelitian Kesehatan. Bandung: PT Refika Aditama.

23. Notoatmodjo, S. 2010. Metodologi Penelitian Kesehatan. Jakarta: Rineka Cipta

24. Sugiyono. 2017. Metode Penelitian Kombinasi (Mixed Methods). Bandung: Alfabeta

25. Arikunto. 2010. Prosedur Penelitian Suatu Pendekatan Praktik. Jakarta: Rineka Cipta. 